\title{
Carbon Stored on Seagrass Community in Marine Nature Tourism Park of Kotania Bay, Western Seram, Indonesia
}

\author{
Mintje Wawo $^{1^{*}}$, Yusli Wardiatno ${ }^{2}$, Luky Adrianto ${ }^{2}$, Dietriech Geoffrey Bengen ${ }^{3}$ \\ ${ }^{1}$ Graduate School of Bogor Agricultural University, Dramaga Main Road, Campus IPB Dramaga, Bogor, Indonesia 16680 \\ ${ }^{2}$ Department of Aquatic Resources Management, Faculty of Fisheries and Marine Science, Bogor Agricultural University, \\ Academic Ring Road, Campus IPB Dramaga,Bogor, Indonesia 16680 \\ ${ }^{3}$ Department of Marine Science and Technology, Faculty of Fisheries and Marine Science, Bogor Agricultural University, \\ Academic Ring Road, Campus IPB Dramaga, Bogor, Indonesia 16680
}

Received Februari 17, 2014/Accepted April 11, 2014

\begin{abstract}
Currently, the function of seagrass community as carbon storage has been discussed in line with "blue carbon" function of that seagrass has. Seagrass bed are a very valuable coastal ecosystem, however, seagrass bed is threatened if compared to other coastal ecosystems, such as mangroves and coral reefs. The threatened seagrass experienced also contributes to its capacity in absorbing $\mathrm{CO}_{2}$ emission from greenhouse gasses such as $\mathrm{CO}_{2}$ emission. Temporal estimation shows that $\mathrm{CO}_{2}$ emission will increase in the coming decade. On the other side, efforts to decrease climate change can be influenced by the existence of seagrass. Informations about existence of seagrass as carbon storage are still very rare or limited. This study was aimed to estimate carbon storage on seagrass community in Marine Nature Tourism Park of Kotania Bay Area, Western Seram, Maluku Province. The quadrat transect method of $0.25 \mathrm{~m}^{2}$ for each plot was used to collect seagrass existence. The content of carbon in the sample of dry biomass of seagrass was analyzed in the laboratory using Walkley \& Black method. The results showed that total carbon stored was higher in both Osi and Burung Islands of Kotania Bay than other studied areas (Buntal and Tatumbu Islands, Marsegu Island, Barnusang Peninsula, Loupessy and Tamanjaya Village). The average carbon stored in Kotania Bay waters was $2.385 \mathrm{MgC} \mathrm{ha}^{-1}$, whereas the total of carbon stored was 2054.4967 MgC.
\end{abstract}

Keywords: biomass, seagrass, blue carbon, carbon stock

*Correspondence author, email: minowawo@yahoo.com, telp:+62-85243003590

\section{Introduction}

Climate change is caused by increasing the concentration of green house gasses $\left(\mathrm{CO}_{2}, \mathrm{CH}_{4}, \mathrm{~N}_{2} \mathrm{O}, \mathrm{HFC}, \mathrm{PFC}\right.$, and $\left.\mathrm{SF}_{6}\right)$ and particles in the atmosphere. There are 3 mechanisms in which the gasses are increase: (1) increases come from burning fossil fuel, realizing green house gasses, $\mathrm{CO}_{2}$ (brown carbon), and ash particle (black carbon), (2) secondly, originates emission from cutting forest vegetation, burning forest, and using fertilizer in agricultural activities, (3) thirdly, the changing of climate is also led by lessening the capability of natural ecosystem to absorb carbon in photosynthesis capacity and saving process, as known green carbon (Trumper et al. 2009). Impact of climate change can lead to increase global temperature above $2{ }^{\circ} \mathrm{C}$ treshold value (Nellemann et al. 2009). In the last several years, scientist have worked together to overcome problems of green carbon, content of carbon stored globally in forest area and soil, through Reduced Emissions from Deforestation and forest Degradation (REDD) program. Degradation of forest in terrestrial area has no far different to coastal area.

The most current issue that become a global issue is a document known as blue carbon launched on $14^{\text {th }}$ October
2009 in Johannesburg, South Africa, by United Nations, UNEP, FAO, and UNESCO. One of the recommendatios is the protection of three coastal ecosystems, mangrove, seagrass, and salt marsh (Hutomo 2009). According to that document, these three coastal ecosystems cover less than $1 \%$ of marine area in the world, however, they have an important role as carbon sink from atmosphere, and through all processes within these ecosystems like photosynthesis directly knock (store) binded carbon from atmosphere in basin waters as many as $50 \%$ (Larkum et al. 2006).

Absorbing carbon from atmosphere seems to be different to phytoplankton which only absorb about $10 \%$ in water basin. Seagrass, therefore, has an essential role as carbon store, and contributes significantly in mitigating global warming due to climate change that happens currently. Protecting organic stored carbon in the forest is assumed as an important method in mitigating climate change. Carbon accumulation in marine sediments provides longterm storage of organic carbon and has been referred to as blue carbon to distinguish it from carbon in terrestrial sinks (Nellemann et al. 2009). Unlike terrestrial systems that store organic carbon primarily in living biomass and soil organic matter, coastal 
vegetated systems store the majority of organic carbon in sediment (Duarte et al. 2005; McLeod et al. 2011; Fourqurean et al. 2012). In addition, terrestrial habitats lose carbon stocks to the atmosphere as $\mathrm{CO}_{2}$ via decomposition or by disturbances such as fires (Schlesinger \& Lichter 2001; Duarte et al. 2011). Because marine sediments are often anoxic and continually accumulate sediment (Kennedy et al. 2010), organic carbon can be preserved within them over decadal to even millennial time scales where the organic carbon, though subjected to some diagenesis, is still considered a carbon sink (McKee et al. 2007).

As same as terrestrial ecosystem, coastal ecosystem also save a huge number of carbon, and has been an initiative for protecting blue carbon source particularly in seagrass (Fourqurean et al. 2012). Seagrass habitat can also save carbon for years as similar as some rooted plant species (Russell et al. 2013). Organic carbon in seagrass sediment, known as blue carbon, accumulates from both in situ production and sedimentation of particulate carbon from the water column (Greiner et al. 2013).

Nowadays facts have already proved that the area of seagrass areas has decreased globally due to threaten of environmental unfriendly development. According to Waycott et al. (2009), lost of seagrass condition and average decrease width tend to increase dramatically over years. Seagrass ecosystems are lost each year through habitat destruction, eutrophication, and other anthropogenic stressors.

Seagrass bed is one of the coastal ecosystem that has an ecological and physical function with economic value and habitat for many marine organism (Jackson et al. 2006). Some of ecological function of seagrass are spawning ground of many organism, feeding ground, nursery ground, connected terrestrian and marine habitat, sediment stabilization that protect coastal erosion etc. (Green \& Short 2003; Eklof et al. 2006; Fonseca \& Koehl 2006; Kennedy \& Bjork 2009). Average of fish abudance was higher in vegetated area than unvegetated area (Rahmawati et al. 2012). Seagrass meadows are highly productive habitats that provide important ecosystem services in the coastal zone, including carbon and nutrient sequestration (Greiner et al. 2013). Moreover, seagrass also has an important function to be considered as carbon storage in accordance to blue carbon concept curently discussed intensively. Seagrass as a valuable coastal ecosystem, however, has undergo more threatened than any other coastal ecosystems (Waycott et al. 2009; Fourqurean 2012).

Due to threaten faced by seagrass ecosystem, the capability to absorb carbon emision has also under threat. Currently, $\mathrm{CO}_{2}$ emission globally will tend to increase in the coming decade (Russell et al. 2013), however, efforts to decrease climate change currently are influenced by sustainability of seagrass. Recently, seagrass meadows have been acknowledged for their carbon storage potential and it has been estimated that globally as much as $19.9 \mathrm{Pg}$ of organic carbon are stored in seagrass meadows. Unlike terrestrial systems that store organic carbon primarily in living biomass and soil organic matter, coastal vegetated systems store the majority of organic carbon in sediment (Fourqureanet al. 2012). Information on seagrass existence related to its capability as carbon storage is still limited particularly in eastern part of Indonesia, therefore, the research on the measurement of carbon stored urgently needed. The research was aimed to measure the content of carbon stored on seagrass community in Marine Nature Tourism Park of Kotania Bay, Western Seram, Maluku Province.

\section{Methods}

The research was conducted during May-July 2011 in Kotania Bay, Western Seram, Maluku Province. Kotania Bay is an area of Marine Nature Tourism Park (MNTP) established since 1999 by Ministry of Forest and Plantation. There are many aspects in every marine conservation area, such as biophysical factors, governance, and social economy, that directly or indirectly affect the total management performance (Dangeubun et al. 2013). In cases where there are multiple user competing and over scarce resources, participation may offer support to decision makers in developing or implementing management plans. Participatory rural approach (PRA) is a approach has been written as "how to" guide stakeholders to employing participatory decision making techniques for resource management in coastal zone (Brown et al. 2001). Sampling sites were determined through PRA activity using community mapping approach that relates to resource uses on seagrass ecosystem by coastal communities. Quadrat transect method was used to collect the data. This method assess the community structure of seagrass meadows along transects (English et al. 1994). A transect was placed perpendicularly to coastline along seagrass area in all research sites. Plot or quadrat was placed along transect with interval of $10 \mathrm{~m}$ (Duarte \& Krikman 2003). Measurement on seagrass coverage area, density and biomass was conducted at a plot of $0.25 \mathrm{~m}^{2}$ width (Short et al. 2004). The measurement of physical data covering site position, temperature, salinity, $\mathrm{pH}$, substrates, was also done simultaneously. There are totally 42 research sites and 437 plots. These plots located were representatively in each site.

Biomass and carbon content were measured on aboveground (Abg) parts of seagrass, covering leaf sheaths and leaf blades, while below-ground (Blg) parts of seagrass, such as roots and rhizomes (Kaldy \& Dunton 2000). The measurement of biomass from 7 species of seagrass were conducted by collecting 2 samples from each species. All of the 14 samples were then weighed to determine their total and partial wet weight (roots, rhizomes, leaf sheaths, and leaf blades). According to Short et al. (2004), sample was then dried up on temperature of $60{ }^{\circ} \mathrm{C}$ to obtain constant weight as dry weight. Carbon contain in the dry weight seagrass samples were then analyzed using method according to Walkley and Black (Schumacher 2002) at the laboratory of Soil Science and Land Resources Department, Bogor Agricultural University. The total dry weight of every parts of each species were obtained by multiplying the number of individual seagrass with the dry weight of the parts. Measuring biomass in gram carbon per meter square $\left(\mathrm{g} \mathrm{C} \mathrm{m}^{-2}\right)$ was conducted according to Barron et al. (2004) which count carbon weight biomass $\mathrm{m}^{-2}$ of seagrass plant from gram dry 
weight which then converted to mol $\mathrm{C}$ with percentage of carbon contain dry weight as shown in Equation [1]. Seagrass biomass can be determined in $\mathrm{g} \mathrm{C} \mathrm{m}^{-2}$. Carbon stored on each part of seagrass was calculated by multiplying dry biomass to content of carbon.

Carbon stored $=$ carbon contained $\times$ dry weight

$$
\left(\mathrm{g} \mathrm{Cm}^{-2}\right) \quad(\% \mathrm{C}) \quad\left(\mathrm{g} \mathrm{m}^{-2}\right)
$$

\section{Results and Discussion}

Seagrass in Kotania Bay area covers 823.615 ha based on recalculation of map figured by Supriyadi (2009). According to the width of seagrass covers, seagrass area was then divided by local communities in mapping area based on their livelihood in seagrass areas as can be seen in Table 1. The existing seagrass in Buntal and Tatumbu Islands as well as Osi and Burung Islands could not be calculated separately due to no boundary among all of the islands.

In general, there were 7 species of seagrass found in this area that belong to 2 families. Seagrass species of Hydrocharitaceae family consists of three species i.e., Enhalus acoroides, Thalassia hemprichii, and Halophila ovalis, whereas, 4 species of seagrass, Cymodocea rotundata, Cymodocea serrulata, Halodule pinifolia, and Syringodium isoetifolium, belong to Cymodoceaceae or Potamogetonaceae family (Table 2). Seagrass species distributed variously in all research sites. Five spesies of seagrass were found in 6 sites, namely Buntal, Tatumbu, Osi, Burung, and Marsegu Islands as well as Barnusang Peninsula, while only 6 and 7 species were existed in Loupessy and Tamanjaya Villages, respectively.

Total density of seagrass species in all research sites was higher than 100 shoot $\mathrm{m}^{-2}$. Marsegu Island was the highest number of seagrass species density which was as many as 556.48 shoot $\mathrm{m}^{-2}$, whereas the lowest number of seagrass species density was Loupessy Village which had 187.83 shoot $\mathrm{m}^{-2}$. The average of seagrass percent cover in the Kotania Bay was generally as many as $50.59 \%$ which ranged $29.23 \%$ (Loupessy Village)-65.17\% (Marsegu Island). The highest seagrass percent cover tends to exist on opened waters area as Marsegu Island if compared to waters of bay intended to land. This condition seems to relate to local community activity that tends to use resource existing in waters of bay far from land.

As can be seen on Table 3, the highest percentage content of carbon in part of seagrass is rhizome belonged to $C$. rotundata $(54.45 \%)$, whereas, the lowest is leaf sheath owned by $H$. ovalis $(32.22 \%)$. This result is also similar to

Table 1 Seagrass area based on local communities mapping in Kotania Bay waters

\begin{tabular}{lc}
\hline \multicolumn{1}{c}{ Research site } & Area (ha) \\
\hline Buntal and Tatumbu Islands & 203.0905 \\
Osi and Burung Islands & 457.0375 \\
Marsegu Islands & 58.1730 \\
Barnusang Peninsula & 94.1635 \\
Loupessy Village & 4.5535 \\
Tamanjaya Village & 6.5970 \\
\hline \multicolumn{1}{c}{ Total } & 823.6150 \\
\hline
\end{tabular}

Table 2 Distribution of seagrass species in all research sites

\begin{tabular}{clllllllllll}
\hline \multirow{2}{*}{ Family } & \multicolumn{1}{c}{ Species } & \multicolumn{7}{c}{ Sites } & & & \\
\cline { 3 - 9 } & & & 1 & 2 & 3 & 4 & 5 & 6 & 7 & 8 \\
\hline \multirow{2}{*}{ Hydrocharitaceae } & Enhalus acoroides & & + & + & + & + & + & + & + & + \\
& Halophila ovalis & & + & + & + & + & + & + & + & + \\
& Thalassia hemprichii & & + & + & + & + & + & + & + & + \\
& Cymodocea rotundata & & + & + & + & + & + & + & + & + \\
& Cymodocea serrulata & & + & + & + & + & + & + & + & + \\
& Halodule pinifolia & & - & - & - & - & - & - & + & + \\
& Syringodium & isoetifolium & & - & - & - & - & - & - & - & + \\
\hline & & Total & 5 & 5 & 5 & 5 & 5 & 5 & 6 & 7 \\
\hline
\end{tabular}

1: Buntal Island; 2: Tatumbu Island; 3: Osi Island; 4: Burung Island; 5:Marsegu Island; 6: Barnusang Peninsula; 7: Loupessy Village, and 8: Taman Jaya Village 
result of Kiswara (2010) that rizhome, a part of seagrass, has the highest percentage of carbon stored which is as many as $50.62 \%$ in E. acoroides, while the lowest is in roots owned by $T$. hemprichii $(26.79 \%)$. Carbon stored and seagrass biomass have corelate to seagrass growth. According to Bjork et al. (2008), variation in characteristic of seagrass growth leads to significant difference of seagrass species from pioneered species to climax species. Pioneered species of seagrass tend to expansively growth, and produce new shoots quickly, therefore, they store a lesser amount of carbon, like Halodule and Halophila spp. In contrast, climax species of seagrass tend to expand slowly, and save massive carbon, namely Thalassia spp and Posidonia oceanica. Kennedy and Bjork (2009) stated that seagrass species that have morphologically large size tend to have more belowground biomass, therefore they can accumulate an enormous number of carbon. For instance, $P$. oceanica, a climax species, needs a slowly longer time to replace roots and rizhomes (taking from 40 days to 19 years) therefore, it can sink a large amount of carbon (40\%) below ground for a longer period. Posidonia oceanica in this example differed to $H$. ovalis in this result which has a smaller percentage of carbon stored if compared to other seagrass species.

According to Kaldy and Dunton (2000), carbon contained is the percentage of carbon element towards dry weight of seagrass in each seagrass species. The result shows below-ground parts of seagrass contain a large amount of carbon especially $E$. acoroides as much as $47.03 \%$. This is in line with the result done by both Duarte (1990) and Rahmawati $(2011 ; 2012)$ that $E$. acoroides had also a huge carbon stored on below-ground, as can be seen in Table 4 . Barnusang Peninsula has a lower carbon stored as much as $198.0147 \mathrm{~g} \mathrm{C} \mathrm{m}^{-2}$ than Loupessy Village (208.7629 $\mathrm{g} \mathrm{C} \mathrm{m}^{-2}$ ) that has a smaller seagrass coverage (Table 5). Moreover, the average biomass (g dry weight) per area unit in Barnusang Peninsula has also a lower value than other research sites (Table 6). Barnusang Peninsula, therefore, has a lesser contribution for saving carbon.

According to Table 5, the average of carbon stored from seven species of seagrass in the waters of Kotania Bay is as much as $2.385 \mathrm{Mg} \mathrm{C} \mathrm{ha}^{-1}$, whereas, the total of carbon stored is $2054.4967 \mathrm{Mg} \mathrm{C}$. The average of carbon stored in Kotania Bay is higher than Belitung Island, eventhough its seagrass coverage has no wider than Belitung Island (Table 7). The

Table 3 Percentage of carbon content $(\% \mathrm{C})$ in all parts of seagrass

\begin{tabular}{lcccccc}
\hline \multicolumn{1}{c}{ Seagrass species } & Roots & Rhizomas & Blg & $\begin{array}{c}\text { Leaf } \\
\text { sheaths }\end{array}$ & $\begin{array}{c}\text { Leaf } \\
\text { blades }\end{array}$ & Abg \\
\hline Cymodocea serrulata & 49.79 & 44.05 & 46.92 & 38.84 & 44.06 & 41.45 \\
Cymodocea rotundata & 34.55 & 54.45 & 44.50 & 45.16 & 46.29 & 45.73 \\
Enhalus acoroides & 41.91 & 52.15 & 47.03 & 40.04 & 43.67 & 41.86 \\
Thalassia hemprichii & 36.26 & 49.18 & 42.72 & 43.92 & 36.74 & 40.33 \\
Syringodium isoetifolium & 43.50 & 46.40 & 44.95 & 46.40 & 40.60 & 43.50 \\
Halodule pinifolia & 34.80 & 46.40 & 40.60 & 32.80 & 43.50 & 38.15 \\
Halophila ovalis & 34.80 & 41.43 & 38.12 & 32.22 & 43.50 & 37.86 \\
\hline \multicolumn{1}{c}{ Average } & $38.75 \pm 5.95$ & $47.72 \pm 4.45$ & 43.55 & $39.91 \pm 6.03$ & $46.62 \pm 3.26$ & 41.17 \\
\hline
\end{tabular}

Blg: Below-ground; Abg: Above-ground

Tabel 4 Percentage of carbon content ( $\%$ C) based on below-ground (Blg) and above-ground (Abg) part of seagrass from different researchers

\begin{tabular}{|c|c|c|c|c|c|c|c|c|}
\hline \multirow{3}{*}{ Seagrass species } & \multicolumn{8}{|c|}{ Percentage of carbon content $(\% \mathrm{C})$} \\
\hline & \multicolumn{4}{|c|}{ Blg } & \multicolumn{4}{|c|}{$\mathrm{Abg}$} \\
\hline & 2011 & 2012 & $2011 *$ & 1990 & 2011 & 2012 & $2011 *$ & 1990 \\
\hline Cymodocea serrulata & 46.92 & 26.46 & 33.5 & - & 41.45 & 29.04 & 32.5 & - \\
\hline Cymodocea rotundata & 44.50 & - & 41.6 & - & 45.73 & - & 40.3 & - \\
\hline Enhalus acoroides & 47.03 & 33.26 & 41.5 & - & 41.86 & 32.26 & 40.2 & - \\
\hline Thalassia hemprichii & 42.72 & 22.54 & 35.6 & - & 40.33 & 25.22 & 36.4 & - \\
\hline Syringodium isoetifolium & 44.95 & - & - & - & 43.50 & - & - & - \\
\hline Halodule pinifolia & 40.60 & - & - & - & 38.15 & - & - & - \\
\hline Halophila ovalis & 38.12 & - & 18.9 & 33.6 & 37.86 & - & 25.2 & 33.6 \\
\hline Halodule uninervis & - & 29.95 & 30.4 & - & - & 31.83 & 33.4 & - \\
\hline
\end{tabular}

Source: Duarte (1990), Rahmawati (2011*; 2012)

Blg: Below-ground; Abg: Above-ground 
Table 5 The total of carbon stored in seagrass of all research sites

\begin{tabular}{lcccc}
\hline \multicolumn{1}{c}{ Sites } & $\begin{array}{c}\mathrm{CS} \\
\left(\mathrm{g} \mathrm{C} \mathrm{m}^{-2}\right)\end{array}$ & $\begin{array}{c}\text { Area } \\
(\mathrm{ha})\end{array}$ & $\begin{array}{c}\mathrm{CS} \\
\left(\mathrm{Mg} \mathrm{C} \mathrm{ha-1}^{-1}\right)\end{array}$ & $\begin{array}{c}\text { Total CS } \\
(\mathrm{Mg} \mathrm{C})\end{array}$ \\
\hline Buntal and Tatumbu Islands & 330.5509 & 203.091 & 3.306 & 671.317 \\
Osi and Burung Islands & 227.8001 & 457.038 & 2.278 & 1041.132 \\
Marsegu Island & 223.6687 & 58.173 & 2.237 & 130.115 \\
Barnusang Peninsula & 198.0147 & 94.164 & 1.980 & 186.458 \\
Loupessy Village & 208.7629 & 4.554 & 2.088 & 9.506 \\
Tamanjaya Village & 242.0653 & 6.597 & 2.421 & 15.969 \\
\hline Average & 238.4771 & & 2.385 \\
\hline Total & \multicolumn{5}{c}{2054.4967} \\
\hline
\end{tabular}

CS: Carbon stored

Table 6 The average of biomass dry weight in seagrass

\begin{tabular}{lcc}
\hline \multicolumn{1}{c}{ Sites } & $\mathrm{g} \mathrm{DW} \mathrm{m}^{-2}$ & $\mathrm{~g} \mathrm{DW} \mathrm{ha}^{-1}$ \\
\hline Buntal Island & 620.24 & 6202370.64 \\
Tatumbu Island & 760.76 & 7607579.66 \\
Osi Island & 509.06 & 5090595.12 \\
Burung Island & 431.06 & 4310561.01 \\
Marsegu Island & 455.90 & 4559016.80 \\
Barnusang Peninsula & 415.70 & 4156988.71 \\
Loupessy Village & 431.45 & 4314505.31 \\
Tamanjaya Village & 504.31 & 5043092.48 \\
\hline Total & 4128.47 & 41284709.73 \\
\hline
\end{tabular}

Table 7 The average of carbon stored in seagrass community at the different sites in Indonesia waters

\begin{tabular}{lccccc}
\hline \multicolumn{1}{c}{ Site } & $\begin{array}{c}\text { Width of } \\
\text { seagrass } \\
\text { (ha) }\end{array}$ & $\begin{array}{c}\text { Number of } \\
\text { species }\end{array}$ & $\begin{array}{c}\text { Average of } \\
\text { covers } \\
(\%)\end{array}$ & $\begin{array}{c}\text { Average of } \\
\text { carbon stored } \\
\left(\mathrm{g} \mathrm{C} \mathrm{m}^{-2}\right)\end{array}$ & Source \\
\hline Pari Island, Seribu Islands & 32.706 & 6 & 23.01 & 200.5 & Rahmawati 2011 \\
Belitung Island & $1,699.000$ & 5 & 13.89 & 54.0 & Rahmawati 2012 \\
Kotania Bay & 823.615 & 7 & 50.59 & 238.5 & \\
\hline
\end{tabular}

balance of carbon contained has been widespread depending on dominant species, interspecific competition, climatic factors (temperature and light), nutrient availability, herbivore pressure, and anthropogenic disturbance (Gattuso et al. 1998). Therefore, seagrass species composition as community compiler can influence carbon stored value of a seagrass community. Carbon accumulation rates for established seagrass meadows vary depending on the seagrass species, sediment characteristics, and depth range of the seagrass habitats (Greiner et al. 2013). The high capacity of seagrass meadows to store $\mathrm{C}$ has been explained to result from the high primary production of seagrass meadows and their capacity to filter out particles from the water column and store them in soils, combined with low decomposition rates in the oxygen-poor seagrass soils and the lack of fires underwater (Hendriks et al. 2007).

According to Nellemann et al. (2009), the amount of $\mathrm{CO}_{2}$ stored can be calculated by converting carbon stored value using the formula of $\mathrm{C}=44 / 12 \mathrm{CO}_{2}$. The amount of $\mathrm{CO}_{2}$ stored, therefore, in Kotania Bay is as many as $559.8 \mathrm{Mg}$ $\mathrm{CO}_{2}$. The capability to save and to absorb $\mathrm{CO}_{2}$ on seagrass community shows seagrass community can play important roles in mitigating climate change in forthcoming years. Russell et al. (2013) stated seagrass is a vegetation that can be used to reduce the $\mathrm{CO}_{2}$ leakage because it can be saveable carbon for years. P. oceanic, for instance, can store carbon as 
much as $12 \%$ in the sea area. It, however, immediately will release $\mathrm{CO}_{2}$ to waters if seagrass has died. Therefore, carbon storage service provided by seagrass can be sustainable through maintaining seagrass coverage and seagrass health (Kennedy \& Bjork 2009). These carbon accumulation rates will be useful for planners and policy makers in assessing the potential of restored seagrass ecosystems to sequester blue carbon (Greiner et al. 2013).

\section{Conclusion}

The rizhome, a part of seagrass, has the highest percentage of carbon stored which is as many as $54.45 \%$ in C. rotundata, while the lowest in is leaf sheath owned by $H$. ovalis $(32.22 \%)$. Seven different species of seagrass found in the waters of Kotania Bay has the average of carbon stored as many as $2.385 \mathrm{Mg} \mathrm{Cha}^{-1}$, as well as the total carbon contained as many as $2054.4967 \mathrm{Mg} \mathrm{C}$. Osi and Burung Islands have the highest total of carbon stored. With relatively small in size and specific seagrass species, Kotania Bay had the capacity to store substantial amount of carbon. For that reason, the management of seagrass at Kotania Bay should compulsory be improved to maintain its capacity to store carbon.

\section{References}

Barron C, Marba N, Terrados J, Kennedy H, Duarte CM. 2004. Community metabolism and carbon budget along a gradient of seagrass (Cymodoea nodusa) colonization. Limnology Oceanografi 49(5):1642-1651 .

Bjork M, Short F, Mcleod E, Beer S. 2008. Managing Seagrasses for Resilience to Climate Change. Gland: IUCN.

Brown K, Tompkins E, Adger WN. 2001. Trade-off analysis for participatory coastal zone decision-making. Norwich: Overseas Development Group, University of East Anglia.

Dangeubun FDW, Wiryawan B, Muataruddin, Purbayanto A. 2013. Management effectiveness of Southeast Aru Islands marine conservation area. Jurnal Managemen Hutan Tropika 19(2):119-127. http://dx.doi.org/10. 7226/jtfm.19.2.119.

Duarte CM. 1990. Seagrass nutrient content. Marine Ecology Progress Series. 67:201-207.

Duarte CM, Kirkman H. 2003. Methods for The Measurement of Seagrass Abundance and Depth Distribution. In: Short FT, Cotes RG, Short CA. 2003. Global Seagrass Research Methods. Amsterdam: Elsevier.

Duarte CM, Middelburg JJ, Caraco N. 2005. Major role of marine vegetation on the oceanic carbon cycle. Biogeosciences 2:1-8. http://dx.doi.org/10.5194/bgd-21-2005.

Duarte CM, Kennedy H, Marba N, Hendricks I. 2011. Assessing the capacity of seagrass meadows for carbon burial: current limitations and future strategies. Ocean
Coastal Management 51:671-688.

Eklof JS, de la Torre-Castro M, Nilsson C, Ronnback P. 2006. How do seaweed farms influence local fishery catches in a seagrass dominated setting in Chwaka-Bay, Zanzibar? Aquatic Living Resources 19:137-147 .

English S, Wilkinson C, Baker V. 1994. Survey manual for tropical marine resources. Australia Townsville: Institute of Marine Science.

Fonseca MS, Koehl MAR. 2006. Flow in seagrass canopies: the influence of patch width. Estuarine, Coastal and Shelf Science 67:1-9.

Fourqurean JWet al. 2012. Seagrass ecosystems as a globally significant carbon stock. Nature Geoscience 5:505-509.http://dx.doi.org/10.1038/NGEO1477.

Gattuso JP, Frankignoulle M, Wollast R. 1998. Carbon and carbonate metabolism in coastal aquatic ecosystems. Annual Review of Ecology, Evolution and Systematic. 29:405-434.

Green EP, Short FT. 2003. World Atlas of Seagrasses. USA: University of California press.

Greiner JT, McGlathery KJ, Gunnell J, McKee BA. 2013. Seagrass restoration enhances "blue carbon" sequestration in coastal waters. PloS ONE 8(8): e72469. http://dx.doi.org/10.1371/journal.pone.0072469.

Hendriks IE, Sintes T, Bouma T, Duarte CM. 2007. Experimental assessment and modeling evaluation of the effects of seagrass (P. oceanica) on flow and particle trapping. Marine Ecology Progress Series 356:163-173.

Hutomo M. 2009. Kebijakan, Strategi dan Rencana Aksi Pengelolaan Ekosistem Lamun di Indonesia. Makalah disampaikan pada Lokakarya Nasional I Pengelolaan Ekosistem Lamun, 18 November 2009, Jakarta: Sheraton Media.

Jackson EL, Attrill MJ, Rowden AA, Jones MB. 2006. Seagrass complexity hierarchies: influence on fish groups around the coast of Jersey (English Channel). Journal of Experimental Marine Biology Ecology 330:38-54.

Kaldy JE, Dunton KH. 2000. Above- and below-ground production, biomass and reproductive ecology of Thalassia testudinum (turtle grass) in a subpical coastal lagoon. Marine Ecology Progress Series 193:271-283.

Kennedy H, Bjork M. 2009. Seagrass Meadows. In: Laffoley DD'A, Grimsditch G, Editors. 2009. The Management of Natural Coastal Carbon Sinks. Glan: IUCN.

Kennedy H, Beggins J, Duarte CM, Fourqurean JW, Holmer M. 2010. Seagrass sediments as a global carbon sink: isotopic constraints. Global Biogeochemical Cycles 


$$
24: 1-8 \text {. }
$$

Kiswara W. 2010. Preliminary study : ability of seagrass beds as carbon stock and carbon sink at Pari Island, Jakarta Bay. Oseanologi Dan Limnologi 36:361-376.

Larkum AWD, Orth RJ, Duarte CM, editors. 2006. Seagrasses: Biology, Ecology and Conservation. Dordrecht: Springer.

McKee LK, Cahoon DR, Feller IC. 2007. Caribbean mangroves adjust to rising sea level through biotic controls on change in soil elevation. Global Ecology Biogeography 16:545-556. http://dx.doi.org/10.1111/j. 1466-8238.2007.00317.x.

McLeod E, Chmura GL, Bouillon S, Salm R, Bjork M. 2011. A blueprint : toward an improvement understanding of the role of vegetated coastal habitats in sequestering $\mathrm{CO}_{2}$. Front Ecology Environment 9:552-560. http://dx.doi. org/10.1890/110004.

Nellemann C et al. 2009. Blue Carbon: The Role of Healty Oceans in Binding Carbon. A Rapid Response Assessment. Birkeland Trykkeri AS: United Nations Environment Programme.

Rahmawati S. 2011. Estimasi cadangan karbon pada komunitas lamun di Pulau Pari, Taman Nasional Kepulauan Seribu, Jakarta. Jurnal Segara 7(1):1-12.

Rahmawati S. 2012. Estimasi Cadangan Karbon Komunitas Padang Lamun di Perairan Barat Pulau Belitung, Provinsi Bangka Belitung. In: Nuchsin R et al, editors. Kondisi lingkungan Pesisir Perairan Pulau Bangka Belitung. Jakarta: LIPI Press.

Rahmawati S, Fahmi, Yusup DS. 2012. Seagrass and coastal fish communities in Kendari Waters, South-East Sulawesi. Jurnal Ilmu Kelautan 17(4):190-198.

Russell BD et al. 2013. Future seagrass beds: Can increased productivity lead to increased carbon storage? Marine Pollution Bulletin 73(2):463-469 http://dx.doi.org/10. 1016/j.marpolbul.2013.01.031

Schlesinger WH, Lichter J. 2001. Limited carbon storage in soil and litter of experimental forest plots under increased atmospheric $\mathrm{Co}_{2}$. Nature 411:466-469. http://dx.doi. org/10.1038/35078060.

Schumacher BA. 2002. Methods for The Determination of Total Organic Carbon (TOC) in Soils and Sediments. USA: United States Environment Protection Agency. Environmental Science Division National.

Short FT, Mckenzie LJ, Coles RG, Gaeckle JL. 2004. Seagrass Net Manual for Scientific Monitoring of Seagrass Habitat. USA: University of New Hampshire, QDPI, Northern Fisheries Centre.

Supriyadi IH. 2009.The mapping of seagrass and asociate biota to seagrass conservation identification at Kotanian and Pelitajaya Bays. Oseanologi dan Limnologi di Indonesia 35:167-183.

Supriyadi IH. 2012. Mengelola Lamun sebagai Ketahanan terhadap Perubahan Iklim Global: Pemetaan Lamun di Perairan Kepulauan Belitung dalam Kondisi Lingkungan Pesisir Perairan Pulau Bangka Belitung. Jakarta: LIPI Press.

Trumper K et al. 2009. The Natural Fix? The Role of Ecosystems in Climate Mitigation. A UNEP Rapid Response Assessment. Cambridge: United Nations Environment Programme, UNEPWCMC. http://www.unep.org/pdf/BioseqRRA_scr.pdf.

Waycott M et al. 2009. Accelerating Loss of Seagrasses Across The Globe Threatens Coastal Ecosystems. Proceedings of The National Academy of Sciences of The USA(PNAS) 106:12377-12381 (28 July 2009). 